\title{
Robert J. Flaherty and Seáinín Tom Ó Dioráin: Lights, Camera, and (Not Too Much) Action
}

\author{
Tomás Ó h-Íde (Ihde) \\ Lehman College, CUNY, USA
}

\begin{abstract}
Copyright (c) 2016 by Tomás Ó h-Íde. This text may be archived and redistributed both in electronic form and in hard copy, provided that the author and journal are properly cited and no fee is charged for access.
\end{abstract}

\begin{abstract}
Famed director Robert Flaherty's first direct sound film, Oidhche Sheanchais, was recently discovered at Harvard University. This article discusses the impact that the discovery will have on our understanding of this short film, especially as concerns film studies and folklore. It notes several misunderstandings reported in the literature over the years that have now been set right with the finding of the film. The article points to resources held in archives in Ireland and the United States that can additionally address questions related to this film. While a noteworthy contribution to the filmography of Robert Flaherty, the short 'talkie' must be approached with caution by folklorists due to the coaching of actors and cinematographic editing.
\end{abstract}

Key Words. Oidhche Sheanchais, Man of Aran, Robert Flaherty, Seáinín Tom, Aran Islands, Maggie Dirrane, Sound Film, Irish Language.

Resumen. La primera película con sonido directo del célebre director Robert Flaherty, titulada Oidhche Sheanchais, fue descubierta recientemente en la Universidad de Harvard. El artículo considera la repercusión de dicho hallazgo en el ámbito del cine y del folklore, y corrige varios errores difundidos durante años en relación a este corto sonoro. Asimismo, se indica la existencia de recursos existentes en archivos de Irlanda y de los Estados Unidos que pueden arrojar luz sobre la película, que si bien constituye una notable contribución a la filmografía de Robert Flaherty, debe ser abordada con cautela debido a la dirección de actores y edición cinematográfica.

Palabras clave. Oidhche Sheanchais, El hombre de Aran, Robert Flaherty, Seáinín Tom, islas Aran, Maggie Dirrane, cine sonoro, lengua irlandesa.

Robert J. Flaherty's 1934 feature movie Man of Aran is a widely discussed and analysed film in Irish Studies, yet few are aware that he also directed the first Irish language sound film entitled Oidhche Sheanchais, "a night of storytelling", a 10-minute film sponsored by the Irish Free State's Department of Education

1. The title of this film would be written "Oíche Sheanchais" using the current orthographic conventions. Either way, it is pronounced /i:x' han $\mathrm{x}$ s'/ following the sound transcription used in the Foclóir Póca dictionary (An Roinn Oideachais 1986). and shown in cinemas in Ireland in $1935,{ }^{1}$ but long thought to have been lost. ${ }^{2}$ However, to the surprise of many, Oidhche Sheanchais surfaced in 2012 at Harvard University's Houghton Library. The restored version, after screening at several international film festivals

2. An tÉireannach Fáin, a documentary about Robert Flaherty which aired in 2010 on the national Irish language television channel, TG4, confirmed the status of lost film. An English-language version of An tÉireannach Fáin premiered in 2011 and was entitled A Boatload of Wild Irishmen. 
and a symposium at Harvard, premiered in Ireland in July 2015. ${ }^{3}$ Some of those in Ireland mentioning the film in their writings prior to its rediscovery included O'Laoghaire (1945: 159), Ó Conluain (1953: 241), Robinson (1986: 165), McIlroy (1988: 31), and Rockett (2003: 544). However as a result of the film being reported as lost, their comments were necessarily brief. Often primary sources, such as newspaper accounts of the day, were contradictory and without access to the film, one could only hypothesize as to the actual details regarding film length, primary actors and crew, use of spoken language, written language appearing on screen, and scenes depicted. While the film was considered lost for more than seven decades, the text of the tale told in the film was always accessible since it appeared in both pamphlet and newspaper article format in the 1930s. Two authors writing in the Irish language a decade ago penned articles that sought to gain a better understanding of this lost film, Nollag Mac Congáil (2003a; 2003b) and Brian Ó Catháin (2004), and researchers now owe much to them for their pioneering work.

This film is remembered today as not only the first Irish language sound film, but also as the first Irish Free State government sponsored film of any language and the first movie of director Robert Flaherty to be shot with sound as opposed to being silent or dubbed. The timing of this film is important to consider. It was shot in early 1934 in London, a period when it was not practical to bring sound recording equipment to a distant filming location. With famed Robert Flaherty already working in Ireland and Britain on the feature film Man of Aran, the Irish Free State Department of Education took advantage of the opportunity and asked him if he would also film a short Irish language "talkie". A set of a hearth typical of an Irish cottage was constructed in London to record image and sound for Oidhche Sheanchais. Whereas Flaherty

3. The film was screened in the Aran Islands on 7 July 2015, at the Galway Film Fleadh on 8 July 2015, and in Dublin at the Irish Film Institute on 9 July 2015. http://www.rte.ie/ten/news/2015/0629/ 711364-flahertys-first-irish-language-talkie-airs/ Accessed on 7/7/15. had previously built sets on location, including a cut-away igloo for Nanook of the North (1922) and a cottage on the Aran Islands for Man of Aran, this would be the first time that Flaherty would use a set removed from the native location of the people to completely film a movie (Barnouw1993: 38, Mullen 1935: 65).

The expectation from the government and the media in Ireland was that Oidhche Sheanchais would be shown as a curtain-raiser to Man of Aran. In January 1934, in the same period as the recording of the sound for Man of Aran, filming for the short was completed. Yet Man of Aran appeared for the first time in Dublin on 6 May 1934 without Oidhche Sheanchais. In fact, Oidhche Sheanchais would not appear in cinemas for another ten months. Was this just a transcription delay or a film editing delay that prevented Oidhche Sheanchais from sharing in the limelight with Man of Aran? A letter in the Oidhche Sheanchais file at the National Folklore Collection, UCD, written on Gaumont-British Picture Corporation Ltd. letterhead by John Goldman ${ }^{4}$ and addressed to Irish Folklore Institute founder and UCD Irish folklore lecturer Séamus Ó Duilearga (James H. Delargy) sheds light on this question. The 20 April 1934 letter indicated that Oidhche Sheanchais was to by no means be shown as a curtain-raiser to Man of Aran in Ireland.

Listen, you realise I hope that this Gaelic folk story is not on any account to be booked to accompany Man of Aran in the theatres, as it would undoubtedly be detrimental to it by anticlimaxing our caste (sic). We hope everyone understands this. And also that this company have (sic) permitted this short to be made on the strict understanding that it is not to be shown in public theatres for profit. ${ }^{5}$

Hence two reasons were given to Ó Duilearga. First it was felt that the appearance of the cast members in the feature film would be anti-climactic if Oidhche Sheanchais were shown first. It has been noted in the literature that the script of a prologue to the Man of Aran

4. John Goldman, who worked on Man of Aran as a cameraman and editor, changed his name to John Monck in the late 1930s.

5. Goldman correspondence to Ó Duilearga held in the National Folklore Collection, UCD. Reprinted with permission. 
which introduces the cast members in English and Irish appeared to similarly not have been used before the feature film (Ó h-Íde 2014: 76). ${ }^{6}$ John Goldman looking back on the Man of Aran experience in 1959 equally indicated that Flaherty "was afraid of anti-climax" in his films. "One of his maxims was "Never reveal anything'." (Calder-Marshall 1963, 161). The second reason given for Oidhche Sheanchais not being used as a curtain-raiser when it premiered in Dublin in May 1934 was that Gaumont British permitted the short film to be produced with the understanding that it would not be shown for profit in cinemas. ${ }^{7}$ The short 'talkie' was meant for the schools of Ireland. While negotiations needed to be worked out over the next few months to permit Oidhche Sheanchais to be viewed in Irish cinemas during St. Patrick's week the following year, it is clear now that it was the Man of Aran producers and Gaumont British that blocked Oidhche Sheanchais from theatres on 6 May 1934 citing that it would have a negative effect on the Man of Aran viewing experience and marketing. ${ }^{8}$

According to the Harvard Film Archive Blog, the few copies of the Oidhche Sheanchais in Ireland were lost to fire in $1943 .{ }^{9}$ Yet a copy had

6. Note that whereas the prologue for Man of Aran was not incorporated into the film, the prologue for Elephant Boy was. The prologue for the 1937 Flaherty film lasted more than two minutes and followed the opening credits and the scroll (formatted as the pages of a book).

7. With this Gaumont British letter considered, the comments attached to the Harvard copy of the film can now be viewed in a different light. While the on-line catalogue at Harvard University indicates for the film "Restricted: "Cannot be publicly exhibited for profit, nor can ownership be transferred from Houghton Library to a third party",, it appears that this profit restriction applied not only to the Harvard copy, but to all copies originally.

8. In the end of 1934, it was reported that an agreement had been reached where "Two-thirds of the receipts would go to the Department and the other third to the distributors". No longer was there talk of the film being distributed to the schools, but rather hope that students and teachers would go to see the film in cinemas ("Subsidised by State..." 1934: 11). been purchased in 1935 by the then Harvard College Library. That copy remained in a locked metal box and was listed in the paperbased card catalogue. In 2012 archivists at Harvard University entered the film into the on-line database and researchers soon discovered the film and delighted at its existence. A team at Harvard including those affiliated with the "Houghton Library, the Department of Celtic Languages and Literatures, the Harvard Film Archive, and the Widener Library" set about to preserve this film and make it available to researchers and the public (Sumner, Hillers, \& McKenna 2015: 5). The film first appeared in the United States at the Lincoln Center Film Festival on 30 September 2014, after having been premiered at Il Cinema Ritrovato in Bologna on 3 July 2014 and followed by Viennale in Vienna on 1 November 2014. The film was shown again publicly in the United States at the Harvard Film Archives in a symposium with invited speakers on 19 February 2015. It continues to be featured in festivals stateside including that of BAM/PFA (UC Berkeley Art Museum \& Pacific Film Archive) on St. Patrick's Day, 2015.

The discovery of the short film will now raise questions in two fields, film studies and folklore. In terms of film studies, one must ask does this short movie in anyway alter the understanding of Flaherty as a director. Is there anything about this "talkie" that contradicts previous assumptions of his style and work? For the folklorist, one must ask to what extent this discovery adds to the repertoire of Irish language folklore collected in the 1930s. Does this film provide an important contribution to the field that was previously lacking? Theoretically speaking, both of these fields have a similar underlying issue. Basically, does there need to be a minimal amount of interference

9. A blog posting in "Harvard Film Archive: News from the HFA's Collections" on 3 July 2014 indicated that the only known copies of the film were destroyed in 1943 in a fire https://blogs. law.harvard.edu/hfacollections2/2014/07/03/robertflahertys-lost-irish-gaelic-film-found-atharvard/. Newspaper reports indicated a fire at the Film Censor's office in Dublin on Molesworth Street on 20 April 1943. See for example, "Film Destroyed in Fire".1943: 2. 
with the subject matter to produce a finished product which appears as close to the documented form as possible? In terms of film, Flaherty's romanticized approach to documentary lead to immediate comments in the press related to the contrived elements of his films. Likewise, in the field of folklore, in the very first issue of the scholarly journal Béaloideas the editor, Séamus Ó Duilearga, gave the following advice, "The collector should record material verbatim, retaining all peculiarities of dialect and making no "corrections"" (Ó Duilearga 1927: 6). One can only imagine the difficulty that Ó Duilearga as a folklorist must have experienced in acting as a consultant in this movie where there were multiple takes and editing.

Turning to the first question, a short account the director will be made. Robert J. Flaherty (1884-1951) is a well-known filmmaker, and it is not necessary to describe his biography in detail here. However, briefly, he was an American-born filmmaker who spent several years in Canada before becoming well-known as a director. His career is notable in film history in that he was able to successfully produce documentary films as feature length movies that would draw crowds to cinemas. He is now known as one of the 'fathers' of documentary film along with John Grierson. Today, Flaherty's films would find themselves somewhere between ethnofiction and docufiction (Ungar 2011: 74, Donato 2007: 200). ${ }^{10}$ Taking large quantities of film footage, he would edit film into a story. From the outset, he would identify some individuals from the population being filmed and create a core family and the story around those characters. The participants had no previous experience with acting but were chosen by Flaherty based on photogenic qualities. While their acting may not have been professional and their relationships contrived, Flaherty's films were hugely popular and viewed as documentaries in the initial decades that followed their release (Williams 2002).

His early feature films included Nanook of

10. “...Henley compares Rouch's mobilization of these processes to those of early documentarians Dziga Vertov and Robert Flaherty, whom he cites as antecedents of what Rouch conceptualized as ethnofiction or shared anthropology." (Ungar 2011: 74). the North (1922), Moana (1926), and Man of Aran (1934). In these he was focused on the exotic with themes based on the human struggle with nature. His film style was identified as "naturalistic documentary" which "deals with man in a state of nature-primitive, unaffected by machinery" (Gray 1950: 46). Gray defined "naturalistic documentary" as

a nontheatrical film, not purely representational, but having a dramatic form, theme, and unity, and taking as its subject, from the actual world, some aspect of the life of man, either in a state of primitive nature or, at least, unaffected by industrialization (46).

Yet this dramatic element present in documentaries left others crying foul play. Audiences assumed that dress and practices depicted in Flaherty's early films were documented as practices of the day and not something from the previous century as was often the case.

In light of the charges of inauthenticity that have dogged the Flahertys since at least the 1930s, it is crucial to remember that reconstructions of authentic cultural customs and simulations of traditional indigenous lifeways were commonly accepted practices in ethnographic film and photography during the early decades of the twentieth century (Hochman 2014: 118).

In George Stoney's 1978 documentary, How the Myth Was Made, Calder-Marshall claimed that Flaherty was not interested in portraying life as it actually was on the Aran Islands in the 1930s. Flaherty was an artist or a film poet. He had a vision and his task was to use what he could document through the lens to express that vision. Yet Brian Winston (1999) rebuked that defence in an article entitled "Documentary: How the Myth Was Deconstructed." The classic documentary tradition contained too many "stagings", "reconstructions," and requests for repetitions. "The tradition Flaherty had founded and in which Stoney had then been working for more than twenty years was declared to be fatally flawed" (73).

If Flaherty's early films are termed "classic documentaries", than the 1978 documentary of Stoney is clearly an example of "direct cinema". Stoney can be seen and heard on the set as the audience traces his steps on the Aran Islands and as he interviews those who took part in Man of Aran two generations earlier. Stoney uses the accepted documentarian approach of the 1970s to defend Flaherty's 
approach of the 1930s. Winston's own documentary on Robert Flaherty which first aired in 2010 and was entitled An tÉireannach Fáin did not provide any shots of the researcher, but did make use of extensive clips from both the 1934 and 1978 films while using the voice of a narrator, professionally trained actor Macdara Ó Fatharta.

Returning to the recently discovered film Oidhche Sheanchais and the question of whether it now alters our understanding of the director, it would appear that the film was similar in some ways to Flaherty's previous projects mentioned above. As indicated, the set of a home was constructed as had been done in previous movies. There was an element of fiction not only as a result of the studio being in London, but also the actors who might not have otherwise decided to spend an evening of storytelling in each other's company. Yet, that struggle with nature that was viewed not only in his previous films, but also in later films is notably missing in Oidhche Sheanchais. However, as a short it cannot be expected that such themes could be fully developed. In any case, this film in Flaherty's eyes was "exotic" as was the case with the feature films before it in his filmography. It captured a common experience he had had while living in Ireland. The Flaherty Papers at Columbia University have pages and pages of tales written by hand during his years in Ireland (Box 29). It is indicated that Flaherty would invite storytellers to his fireside at what he would identify as Crookawn Glos (Cnocán Glas), to his rented residence beside the constructed Man of Aran cottage, to share folklore which would be readily translated into English. Additionally, Flaherty indicated that Maggie Dirrane was an excellent storyteller. ${ }^{11}$ This interest in folklore can be seen in his research and planning for other films, but only appears on the screen as a primary focus in the film Oidhche Sheanchais.

Before discussing the first question, the value of this find to film studies, any further, it is necessary to turn to the second question concerning folklore. The seanchai or storyteller of the film Oidhche Sheanchais was Seáinín Tom Ó Dioráin; ${ }^{12}$ that was the screen

11. Flaherty Papers, Columbia University, Box 29, an unpublished account entitled "Maggie" by R.J. Flaherty. name that appeared for this actor in the rolling scroll of the 1935 film. ${ }^{13}$ This version of his name was composed from a combination of his local name and an Irish language version of his surname. ${ }^{14}$ Locally he was known as Seáinín Tom Sheáin, a double patronym common in Irish-speaking areas. He was born in the beginning of the $1870 \mathrm{~s}$ in the village of Sruthán on the island of Árainn (commonly known as Inishmore by English speakers), just west on the road from the location where Flaherty would eventually build the Man of Aran cottage. ${ }^{15}$

Seáinín Tom's parents were Thomas (Tom) Dirrane and Mary Mullen. ${ }^{16}$ On the 1901 census, which he signed, he spelled his surname "Dirrane". We see the same "John Dirrane" spelling in his baptism record, marriage record, and the initial death reports in the newspapers. He was married to Catherine Cooke of Bun Gabhla, and they had at least five children. ${ }^{17} \mathrm{He}$ was a farmer (landholder) and

12. Following the lead of Ó Catháin (2004: 153), this article makes use of the individual's names as they originally appeared in Man of Aran and, by extension, Oidhche Sheanchais.

13. Kevin Rockett noted in 1996 in The Irish Filmography, "One review (SI 17/3/1935:4) identifies the seanchai as Sean Tom Sheain who is said to relate a tale of Mairtín 'oc Conraoi, while another (IT 19/3/1935:4) identifies the seanchai as Tomás Ó Dioráin" (14). Actually the Irish Times error goes back further than that. In an article three months earlier on 18 December 1934 (4), the Irish Times cinema correspondent attended a private screening of Oidhche Sheanchais and wrote extensively of the film erroneously referring to Seáinín Tom as "Tomás". No other newspaper appears to have copied this error; however, some of those writing about the film since have repeated the error right up to the present day.

14. It should be noted that the English version of Dirrane (Derrane) was and is used for both Ó Dioráin and Ó Direáin.

15. Árainn is the official placename for Inishmore, Aran Islands.

16. His baptismal record lists his parents and is dated 26 February 1873. http://www.rootsireland.ie

17. See Civil Marriage Record. The Church Marriage Record confirms spouse name. Date of marriage is reported as 28 January 1896. http://www.rootsireland.ie. Ó Catháin reports Seáinín Tom's wife's name as Ceaitín Neilín Ní Chuacach (2004: 171). 
fisherman as would be the case with many of his fellow islanders. He was known as Seáinín Tom in his community, and this was the most common way of referring to the storyteller in newspapers of the day from 1934 to 1936.

Folklore was taken down from Seáinín Tom by a number of collectors over the years. The primary collector was Micheál Seósamh Ó Flannagáin, the local school master. Three of Seáinín Tom's tales were also recorded through the intervention of Séamus Ó Duilearga during a trip to London in January 1934 (Ó Duilearga 1934: 455). ${ }^{18}$ Two of those tales were recorded on Parlophone record and the third tale, the topic of this article, was famously told in the first Irish-language talkie, Oidhche Sheanchais. It was through the intervention of these folklore collectors, Seósamh Ó Flannagáin and Séamus Ó Duilearga, that Robert Flaherty and Seáinín Tom were brought together to create Oidhche Sheanchais. After the film appeared in cinemas, Seáinín Tom continued to live in Árainn and Ó Flannagáin still had folklore

18. The London recordings took place in January 1934 as documented with expense reports in the "Oidhche Sheanchais" file at the National Folklore Collection archives, and not in the month of February. It should be noted that in the same way that Adolf Mahr, National Museum of Ireland, was used as a scholarly expert for Man of Aran, Séamus Ó Duilearga acted as consultant for Oidhche Sheanchais. However, while Mahr wrote several letters to Flaherty regarding the basking shark, Ó Duilearga had a more active role with Oidhche Sheanchais, the film for the Irish Department of Education. He was entrusted with the responsibility of selecting the storyteller and travelled with the storyteller to London in January 1934. He oversaw the folkloristic and linguistic content of the film. As a founder of the folklore movement in Ireland, he was well positioned for such a responsibility. In addition to founding the Folklore of Ireland Society and serving as the founding editor of its scholarly journal, Béaloideas, from 1927 on, he was also instrumental in the establishment of the Irish Folklore Institute in 1930 and the more prominent Irish Folklore Commission in 1935. (Briody 2007: 76). Serving as a Lecturer of Irish Folklore at University College Dublin throughout these years, he was named to the prestigious title of Professor of Irish Folklore, UCD, in 1946. ("New Professors of N.U.I." Irish Independent. 12 April. 5). collected from this seanchaí. Tragically both Seáinín Tom and Ó Flannagáin were killed in a boating accident in 1939, just four years after the release of the film.

So it would appear, in response to the second research question, that this film is an important find for folklore studies. While the tale in the story had been published in the 1930s in newspapers and booklet form, having the film provides another window into the work of Séamus Ó Duilearga and complements the repertoire of folklore collected from Seáinín Tom. It provides one view of a storytelling experience that was not previously available to the student and scholar of folklore.

Researchers can now view copies of the recently re-discovered Oidhche Sheanchais at Harvard University and the Irish Film Institute. Sumner, Hillers, and McKenna also report that copies will be available in the National Folklore Collection, UCD, and the county library in Árainn (2015: 17, f23). However, unlike Man of Aran which can be purchased on DVD and streamed on-line with Amazon.com, Oidhche Sheanchais is not currently available for sale or streaming. Short of booking a visit to one of these archives, the reader will find a detailed description of the film here. The film begins similar to a silent film with no sound and a reliance on the written word. The first five seconds have the shield of the Saorstát Éireann (Irish Free State) making it clear who the sponsor of the film was. The opening credits are then superimposed on this image of the Free State shield and the credits state that the film was intended for the people of the Free State. The credits acknowledge GaumontBritish Picture Corporation Limited as the film company and the location of the actual studio as Gainsborough Studios, Islington, London. The credits are completely in Irish and the title as expected is Oidhche Sheanchais. Only Robert Flaherty, John Goldman, and Séamus Ó Duilearga are acknowledged in these credits. John Greenwood who composed the musical score for Man of Aran and Elephant Boy is notably missing. There is no background orchestral music in this short film except at the very end when the "Crío" (that is "the end") sign appears (the only text on screen to be spelt with the dot of lenition above the "c" instead of "ch"). 
The trademark at the bottom of the credits is notable and reads "British Acoustic Film: New Process Recording". British Acoustic Film was a subsidiary of Gaumont and produced sound systems for movie theatres as well as projectors and cameras. ${ }^{19}$ This same trademark appears on Man of Aran as well as reference to the Islington studio. However the Man of Aran credits extend for five screens listing actors and all the leading individuals who collaborated on the film. The Oidhche Sheanchais credits last for only twenty seconds and are contained in one frame. Neither here nor at the end of the film were the names of the actors or other such credits displayed in the original 1935 movie.

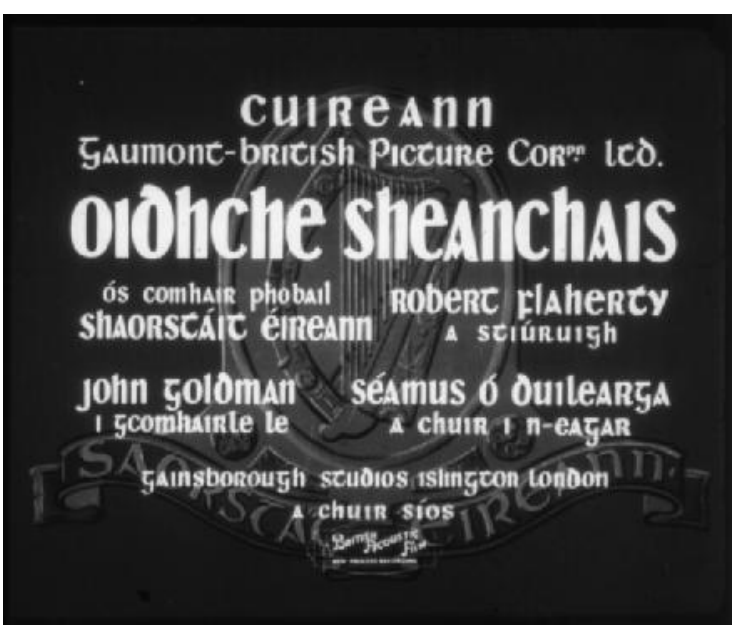

FIGURE 1. The title screen. Oidhche Sheanchais, directed by Robert Flaherty, Gaumont-British, 1935. Image courtesy of the Harvard Film Archive.

Similar to Man of Aran, the screen then fades to the opening scroll. In Oidhche Sheanchais the scroll text is completely in Irish and there is still no sound at this point. In the 1930s many cinema organists continued to play even after the introduction of sound film, playing for example between movies.

The opening scroll in Oidhche Sheanchais shares the idea that some of the traditions on the Aran Islands hark back to the Middle Ages. We also see this in the introduction to the printed pamphlet version of the tale: "Ar Oileáin Árann, teorainn thiar na nGaedheal, tá roinnt de na

19. Minister for Education Thomas Derrig noted in the Dáil that a "payment of a royalty of $£ 20$ to British Acoustics" were among additional expenses to the Irish Free State in the production of the film. (Dáil Éreann Debates 1934: 54.9). nósanna a bhain le muinntir na hEorpa sa Meadhon-Aois beo fós...."20 This concept was very attractive to director Robert Flaherty. We know that he read Synge's The Aran Islands which first appeared in 1906 (Calder-Marshall 1966: 142). For example, a similar idea was expressed there, "Every article on these islands has an almost personal character, which gives this life, where all art is unknown, something of the artistic beauty of medieval life" (18). The opening scroll in Oidhche Sheanchais emphasizes that storytelling is one such custom of the Middle Ages that survives on the Aran Islands. While the actors in the curtain raiser are not named in the credits, the storyteller is identified in this opening scroll as mentioned above as "Seáinín Tom Ó Dioráin". The scroll lasts about twentyfive seconds before fading to the fireside set.

One unexpected discovery now that the film can be seen is that the scroll text in Oidhche Sheanchais uses a sans-serif Roman typeface and the letter " $h$ " to indicate lenition. ${ }^{21}$ Both of these characteristics give the scroll a very modern appearance for a 1935 film. The opening credits also use the letter " $h$ " for lenition, but are in the Gaelic typeface as can be seen in Figure $1 .{ }^{22}$ In comparison, Man of Aran also uses the same Gaelic typeface for the title screens. However, an old style serif Roman typeface

20. On the Aran Islands, western border of the Gael, some of the customs related to the people of Europe in the Middle Ages are still alive... (h of lenition added in place of dot of lenition in quoted text). Roinn an Oidea ais. 1934: 2.

21. Although the English language for the most part only modifies the ends of words (-s, -ed, -ing, for example), the Irish language additionally modifies the beginnings of words. There are two forms of initial mutation seen in Irish, lenition and eclipsis. Lenition, discussed here, involves the softening of the initial consonant. Prior to the spelling reform of the 1940s, this was most commonly indicated with a dot above the consonant. Today, an " $h$ " following the affected consonant is used to indicate lenition.

22. Gaelic type has its origins in the Irish uncial alphabet. It is based on the Latin alphabet and is seen in medieval manuscripts as insular script. 
is used for the scroll giving it a more traditional look.

Those listening to Seáinín Tom at the fireside are the lead actors in Man of Aran who were in London to record sound for that film: Maggie Dirrane with Patch Ruadh seated to her right. Maggie is singing a song in a jovial manner and Patch Ruadh is looking in her direction. He encourages her between lines with expressions such as "Dia leat" (God bless you). Michael Dillane and Tiger King can be seen silently listening, the former seated before the hearth and the latter standing to the side. It is not until the end of her song that the camera finally pans to the left of the hearth, and we see that Seáinín Tom is seated there.

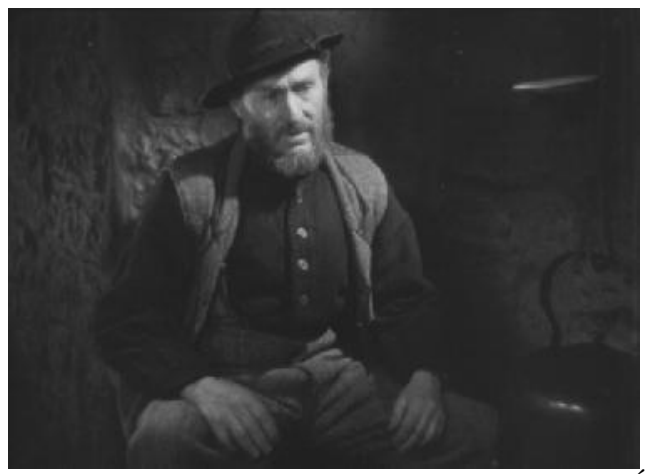

FIGURE 2. The camera view of Seáinín Tom Ó Dioráin in the final third of the film. Oidhche Sheanchais 1935. Image courtesy of the Harvard Film Archive.

Before summarizing the story that Seáinín Tom tells, a few general remarks need to be made. The view of the storyteller and audience changes as one would expect throughout the story with the whole group viewed, Seáinín Tom side view, a close up of Maggie, a front view of Seáinín Tom and so on. The audio appears to be taken from three primary clips. Other images of the audience listening are then edited in preserving the soundtrack of these three primary recordings. The first segment starts with Maggie and pans to Seáinín Tom at the beginning of his story, the second segment is of the entire group seated around the fireplace, and the third segment uses a front view of Seáinín Tom on his own starting with the words, "Bhí cos a' píce amach ón éadach". ${ }^{23}$ The second segment is the longest upon which other

23. "The end of the pike was sticking out of the bedclothes". images are often edited while maintaining the primary soundtrack. ${ }^{24}$ It is not likely that three cameras were rolling during the session, but rather that the movie was filmed multiple times and the primary segments were spliced. Since the sound was recorded while filming, the editing could maintain synchronization throughout. Over all it is an excellent editing job and the movie displays a much higher image quality than seen in Man of Aran as a result of studio conditions.

The story that Seáinín Tom tells, "Máirtín 'ac Conraoi", comes from a native Irish repertoire that involves seafaring people and therefore would have complemented the movie, Man of Aran, had it been shown as a curtain-raiser in 1934. The story was distributed by the Department of Education in pamphlet form and reprinted in the Irish Press twice so that teachers could review the tale with students before they saw the movie. The focus of the film was to expose the children of Ireland to the storytelling experience and in one theatre the film was shown for a week before a children's feature film reinforcing this goal (Ó h-Íde 2014, 78).

In this story an elderly fisherman, Máirtín 'ac Conraoi, who has only his three sons, sends them out to check the family fishing lines. As the sons get ready to depart, the father pleads with them to take the "píce agus an splannc". ${ }^{25}$ He starts with the oldest on down. It is the youngest son, who agrees to take the fork and glowing embers. The sea is rough and takes many lives. A great wave approaches the boat of the three sons. The older brothers assume that they will soon be drown. But the youngest son picks up the pike and burning sod and throws them at the wave which immediately flattens. A few days after that, an elegantly dressed

24. The view of this segment can be seen in Ó h-Íde 2014: 70 .

25. Ó Duilearga uses this Irish language quote without translation in his English summary of the tale (NFC 287: 62-80). His contemporary Seán Ó Súilleabháin, archivist of the Irish Folklore Commission, refers to this in English as a "burning sod of turf borne on a pike" used most commonly by a woman to "ward off evil spirits". Ó Súilleabháin, Seán1970: 411. 
man comes calling at the house of Máirtín 'ac Conraoi. He requests that the youngest son go with him for an hour, and he promises that he will be brought back unharmed. They travel by way of a magical horse to the fairy castle to visit the Queen. She is lying down in bed, and the handle of the fork can be seen protruding. It is lodged in queen's side, and only the one who placed it there can dislodge it. The elegantly dressed man reveals that he is king of the fairy dwelling and this wounded young woman is his wife. The youngest son successfully removes the pike and embers and as a result his family is rewarded. While this legend has been collected widely in Ireland, the version told by Seáinín Tom up until recently was only available in printed format.

Since the film can now be viewed, it is time to revisit a number of contradictory details that have been reported about this movie and discuss what bearing they have on the two questions raised initially in this article. There has been some controversy as to what extent Robert Flaherty was involved with the film and while he was undoubtedly associated with the film, it was not clear to what extent he affiliated himself with it. The only direct reference to Oidhche Sheanchais discovered in the 80 boxes of the Flaherty Papers at Columbia University is one newspaper clipping mentioning the premiere of the film (Scrapbooks, Flaherty Papers). No notes or correspondence related to the film appears to be held there. Now that the film and the opening credits can be seen, that discussion is laid to rest. He clearly took full credit for the film with Gaumont-British indicating that it was "Robert Flaherty a stiúruigh". ${ }^{26}$ So returning to the first research question, this film obviously needs to be added to Flaherty's filmography regardless of the importance to its impact on his repertoire. Some websites hastily added the film to his list of movies after the publicized find. However, most filmographies were published years ago and as long as those volumes are used as major references in Flaherty research, Oidhche Sheanchais will occasionally continue to remain outside the filmography (Ó Catháin 2004: 151).

It was never reported in scholarly writings before the film was found what song Maggie

26. Directed by Robert Flaherty. sang in Oidhche Sheanchais. Much greater focus has been on the tale. We now know one reason why. Only five couplets of Maggie's song are heard in the film, yet the entire tale of Seáinín Tom is included (Sumner, Hillers, and McKenna 2015: 10). The film begins as Maggie is nearly done singing the song and the movie viewers hear less than a minute of her singing. Seáinín Tom's tale, in comparison, takes nearly nine minutes of the movie to share. Twenty years after the film was made, Maggie stated to Sidney Robertson Cowell that a song she sang for her was called "Baile an Róba”.

In fact, the first words of her complete version of that song were "[Is] i mBaile an Róba.... ${ }^{, 27}$ It is clear now that the song in the 1935 film is the end of that same song recorded by Sidney Robertson Cowell in 1955. The notes that accompany the catalogue entry for the recording in the Smithsonian Institution indicate that Maggie's version of "Baile an Róba" is a mixture of more than one song. Sumner, Hillers, and McKenna provide a transcription and translation of Maggie's singing in the film (2015: 9-10).

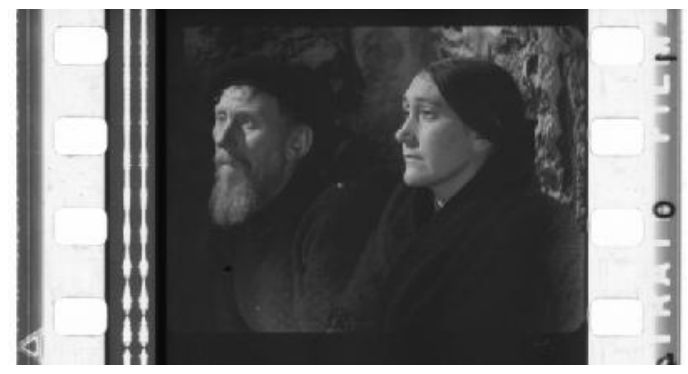

FIGURE 3. Close up of Maggie and Patch Ruadh that was edited into the movie. Note sound recording of Seáinín Tom speaking immediately to left of picture. Oidhche Sheanchais 1935. Image courtesy of the Harvard Film Archive.

Despite Maggie's singing performance in the night of storytelling being so short, she and Seáinín Tom grace the silver screen for nearly the same amount of time. In fact, when comparing the number of seconds that the camera focuses on either of the actors (where the individual appears alone or with just one other actor), surprisingly Maggie has more close-up time in the film than does the star Seáinín Tom. It could be argued that whereas the lead actors in Man of Aran were chosen for

27. "[It is] in Ballinrobe ...." 
their photogenic qualities, Seáinín Tom was clearly chosen for his ability to tell a story. However, newspapers of the day did not report that Ó Duilearga selected Seáinín Tom primarily for his repertoire, but rather his voice/linguistic ability. The Irish Press on 14 December 1934 on page 9 in an article entitled "First 'Talkie' in Irish" reported "After visiting various parts of Connemara he finally chose Seánín (sic) for his fine features and his perfect enunciation." The same newspaper the following day in an article entitled simply "Gaelic Films" on page 8 indicated, "The fact that Mr. Seamus Delargy, of University College, Dublin, supervised the vocal portions of the film gives the final assurance that the language we shall hear is true Western Irish."

The published transcription of the tale in the 1930s did not identify who was speaking. It could be assumed that the main text represented what Seáinín Tom was saying and the bracketed text was undoubtedly one of the islanders listening to the story and making comments. By seeing the film, it can now be observed that the text in brackets is Maggie speaking. Only part of that which she says is transcribed in the 1934 pamphlet, and these are basically words of encouragement. While Patch Ruadh has a few words of support to say during the song such as "Dia leat!" and "Croch suas é!", it is Maggie who does the commenting during the storytelling for the most part with comments such as "Ba bhocht an scéal é!" and "Buíochas le Dia!"28 Tiger King and young Michael Dillane say just a few words each in this film.

Another revelation is that this film includes no footage of crashing Aran waves. It was believed that the film would contain footage from Man of Aran. The Irish Independent reported on 15 July 1933, "According to the present plans, we will see and hear the seanchaí telling the story - with, of course, appropriate setting and possibly a few very brief introductory scenic "shots", (4). Rockett echoed this belief that "Off-cuts of seascapes from Man of Aran were intercut with Ó Dioráin's dialogue" (1996: 14). None of those

28. The phrases in Irish are as follows, "God bless you", "Sing up", "It was a sad state of affairs", and "Thanks be to God" (translations from Ó Dónaill 1977). views made it into the final copy of Oidhche Sheanchais. Rather Flaherty decided to go with close ups of Maggie, Patch Ruadh, and young Michael Dillane as they listened to Seáinín Tom's story. It would appear that Flaherty took a true interest in this film committing to an extra day of filming to get the close ups rather than using images previously taken of crashing waves.

One question that Ó Catháin (2004: 226 fn 71) raised a decade before the film's discovery regards the origin of the photographs that appeared in newspapers, for example in the Irish Press on 15 March 1935. The photo shows Seáinín Tom seated facing to the right by the fire with a kettle hanging over it (4). While this pose looks very much like that at the end of the first segment mentioned above, it is not a still frame from the final version of the 1935 film. The photo for the newspaper must have been either a posed publicity photograph or a still from footage that did not make it into the film. This is also the case for the photo of the entire cast listening to Seáinín Tom that appeared in the Cork Examiner on the same day (6). The caption claims that it is "a scene from the All-Gaelic Film, 'Oidhche Sheanchais"; yet with the film now discovered, it can be seen that this exact pose does not appear in the film. Young Michael Dillane has been repositioned so that his face can be seen in the still photo. In the film, his back is to the camera when the whole group of actors is seen.

Lastly one area of criticism is that there was not much action. Ernest Blythe who was a senator in 1934 and later would leave politics and serve as managing director of the Abbey Theatre described the topic of folklore as dull (Seanad Éireann Debate 1935). The reviewer in the newspaper An t-Eireannach (30 March 1935) indicated that the Irish Government should have,

\section{...sompla maith de pheictiúr a chur ós comhair an phobail - peictiúr gníomhach a thiubharfadh le tuigsint do'n lucht éisteachta céard a bheadh ar siubhal.... Níor chóir go mbeidh na h-aisteoirí ins an bpeictiúr seo chomh roighin marbh agus a bhíodar. $^{29}$}

29. “...put a good example of a picture before the public - a picture with action that would help the audience to understand what was going on. The $\cdot /$. 
Now that the film can be seen, it is true that there was little action on the set. No one ever moved from their positions. The only action that we have is Maggie moving her arm in a swinging motion at the end of the song and Seáinín Tom using his hands at significant moments in the story. It should be noted that Seáinín Tom's hand movements do assist in comprehending the tale. For example, when he says that the gentleman wore a caroline, he touches his hat. Although there was little movement in the film, the few gestures that existed were not noted in detail before the film went missing and are only now accessible to researchers.

There have been many false suppositions regarding this movie in the past including references to Tiger King and Seáinín Tom as not being from Árainn, yet those could be cleared up by careful examination of newspapers of the day and recently released census data (Ó h-Íde 2014: 77; O'Leary 2004: $500)$. However most of the questions addressed in this article could only have been answered by actually finding the film. Other issues remain that will not be as easily answered concerning scholarly interpretation of the findings.

One major area that remains controversial is the goal of producing this film. While the stated aim of the movie was to share the storytelling experience with the school children of Ireland, researchers appear to interpret the method for doing this differently. Ó Catháin stated over ten years ago that the primary goal of the film was to preserve "... ar ghné amháin de thraidisiún beo na Gaeilge - i. ar an scéalaíocht - a bhí Roinn an Oideachais a chur ar fáil sa scannán faisnéise seo lena úsáid sna scoileanna". (bold added here) ${ }^{30}$

While those in the Irish Government may have promised a film for the schools, in reality this may not have been easily carried out. Initially there appeared to have been only three

. actors in this picture should not have been as stiff and dead as they were". Quote and translation from O'Leary 2004: $500 \& 672$.

30 . "... one aspect of the living tradition of the Irish language - i.e. storytelling - which the Department of Education was making available in this documentary film for use in schools". Ó Catháin 2004: 152 or four copies of the film. Newspaper reports identified that the film was screened in two Dublin cinemas for the period of a week and in Cork as well, accounting for three copies during St. Patrick's Day week, 1935. The Connacht Tribune announced the screening in the Savoy Cinema, Galway, some weeks later in the 27 April 1935 edition of their paper (6). The Savoy opened only a few months before that. "It was equipped with the latest in cinema technology which included a High Fidelity sound machine, the first of its kind to be installed in the Irish Free State" (Henry 2014: 34).

Primary or secondary sources that hint that the film ever made its rounds to schools and halls of Ireland are scarce. The reason for this was perhaps the change of technology as mentioned above. Major movie theatres were just being equipped with the latest technology of displaying sound film. ${ }^{31}$ The chances that a trade hall or national school might have the equipment needed to screen this film were slim. Basically, Oidhche Sheanchais was too modern for its day. Silent film continued to appear in cinemas for another decade. The sound-on-disk projectors were the common mobile system for talkies for small groups at this time. One might suspect that the politicians of the early 1930s did not completely think this through when they approved the expenditure. Their experience had been of silent films that were easily screened in any venue that had something upon which to project and a room that could be darkened. What were the chances that a classroom in West Galway might screen the first direct sound movie in Irish? A silent film with intertitles in Irish might have been a better start for the Department of Education, entering into film slowly in stages rather than jumping into the latest technology that only a cinema or large school could access.

31. "By the end of 1929 , only 18 percent of European theaters could present talkies, which nearly half of the cinemas in the United States could. But succession of wiring followed the U.S. model. In all cases the most deluxe picture palaces (super-cinemas) in the biggest cities were wired first. Then cinemas with less revenue-generating potential converted. Very small houses (100 to 200 seats) came last, some as late as 1935" (Gomery 2004: 107). 
In conclusion, the re-discovery of this film will be of notable interest to those in film studies and folklore studies. The film appears to confirm some past practices of the director while it brings into question other approaches. Similar to previous movies, there is a sense of deception in that the film was recorded in a studio and the participants did not just happen to stop by someone's house for an evening of storytelling. However, unlike shark hunting in Man of Aran, no one in Oidhche Sheanchais needed to re-learn or be taught for the first time a skill to act out on the screen. Maggie was a noted traditional singer and Seáinín Tom a respected storyteller. This film does not demonstrate a struggle of any sort, be it with nature or industrialization, as was typical of Flaherty's style. But most remarkable, in this short, Flaherty appears to be filming a social institution, "a night of storytelling." " stark contrast to Man of Aran where the lack of gatherings such as religious services or evenings at the pub are notably missing.

In terms of folklore, it has been remarked above that this film complements the collection of tales amassed by Ó Duilearga. However, the most remarkable characteristic of this film is that it is not just a taping from start to finish of a seanchai telling a tale. It is not similar to a tale recorded on a Dictaphone in the field. Rather in classic Flaherty style, this film documents an aspect of a traditional group of people while truly directing them and editing several takes of footage. One does very much get the feeling that these individuals are acting in subtle ways on the screen. From a documentarian's perspective, the point in the film at which Seáinín Tom asks the audience if they have ever heard the tale called "Máirtín "ac Conraoi" and the members of the cast

32. This practice, a "night of storytelling" has been traditionally called a "céilî". It included both recitation (tales and poems) and music (songs and tunes) by the fireside. The term céilí is now used more generally to describe any gathering including especially music and dance. respond that they have not makes it obvious that there is an element of fiction in this film. The cast must have been growing weary of hearing the tale by this point. This can especially be observed in Maggie, with her well-placed facial expressions and constant glances to Patch Ruadh and young Michael Dillane. The glances appear sincere, though likely coached. ${ }^{33}$ While a primary goal was to preserve the tradition of storytelling on sound film, this was not a "fly on the wall" sort of production. This is a skilled theatrical presentation. Seáinín Tom and Maggie knew their folklore before meeting Flaherty, yet he offered his artistic skills to direct and edit an evening of storytelling worthy of the silver screen. While this does heighten interest in the field of film studies, the value of this film in the field of folklore will be limited to capturing on film a storyteller, documenting his dialect and noting his connection to Ó Duilearga. The tale itself as seen in the film needs to be approached with caution by folklorists since it was edited and it appears that the actors were coached. $^{34}$

33. Outtakes from Man of Aran discovered at the IFI Irish Film Archives and included on the Park Circus DVD Man of Aran show young Michael Dillane being coached with facial expressions again and again.

34. This is a revised version of a paper presented at the Columbia University Irish Studies Seminar on 6 February 2015. The author wishes to thank Leslie Morris of the Houghton Library who facilitated access to the film and Brittany Gravely of the Harvard Film Archive who granted permission to publish stills from the film. Additionally, he would like to thank Ríonach uí Ógáin, director of the The National Folklore Collection, UCD (henceforth NFC), for permission to publish the quote from John Goldman's letter to Séamus Ó Duilearga and archivist Críostóir Mac Cárthaigh of the NFC for assistance in locating primary documents. Lastly, the author would like to acknowledge suggestions received from colleagues Terry Byrne, Deirdre O’Boy, and John Gillen. 


\section{Works Cited}

Publications

An tÉireannach Fáin, directed by Mac Dara Ó Curraidhín and written by Brian Winston. 2010. An Spidéal: LMDÓC_-Léirithe le Mac Dara Ó Curraidhín, shown on TG4 on December 30, 2010.

Barnouw, Erik. 1993 (1974). Documentary: A history of the non-fiction film. New York: Oxford University Press.

Briody, Mícheál. 2007. The Irish Folklore Commission 1935-1970: History, ideology, methodology. Helsinki: Finish Literature Society.

Calder-Marshall, Arthur. 1966. The Innocent Eye: The Life of Robert J. Flaherty. New York: Harcourt, Brace \& World.

Christopher, Robert J. 2005. Robert and Frances Flaherty: A Documentary Life, 1883-1922. Montreal: McGillQueen's University Press.

Dáil Éireann Debates, 54.9, "Committee on Finance. - Vote 49 - Science and Art". 18 December 1934. http://oireachtasdebates.oireachtas.ie/. Accessed 14/7/2015.

Donato, Raffaele. 2007. "Docufictions: an interview with Martin Scorsese on documentary film". Film History. Vol. 19. 199-207.

Farrell, Jim. 1973. "Robert Joseph Flaherty 1884-1951". Thunder Bay Museum. http://www.thunderbaymuseum.com/exhibits/virtual-exhibits/robert-joseph-flaherty/. Accessed 13/7/2015.

"Film Destroyed in Fire".1943: Irish Independent 21 April. 2.

Gomery, Douglas. 2004. The Coming of Sound. New York: Routledge.

Gray, Hugh. 1950. "Robert Flaherty and the Naturalistic Documentary". Hollywood Quarterly 5.1, 41-8.

Henry, William. 2014. "Talking History: The Savoy Cinema". Galway Independent 19 November. 34.

Hochman, Brian. 2014. Savage Preservation: The Ethnographic Origins of Modern Media Technology. Minneapolis: University of Minnesota Press.

J.A.P. 1933. "The World of Films: Is the First Gaelic 'Talkie' Worth While?” The Irish Independent. 15 July. 4.

Mac Congáil, Nollaig. 2003a. "Man of Aran agus Scannán Gaeilge le Robert Flaherty". Feasta 56.2 (Feburary): http://feasta.ie/2003/feabhra/alt5.html.

Mac Congáil, Nollaig. 2003b. "Man of Aran agus Scannán Gaeilge le Robert Flaherty (Cuid 2)." Feasta 56.3 (March): http://www.feasta.ie/2003/marta/alt5.html.

“"Man of Aran': Ready for Exhibition When Dublin Cinema Can Be Secured”.1934. Irish Press 28 March. 2.

“'Man of Aran' to have Brilliant Dublin Premiere”.1934. Sunday Independent 6 May. 4.

Mcllroy, Brian. 1988. World Cinema 4: Ireland. Trowbridge, Wiltshire: Flicks Books.

Mullen, Pat. 1970 (1935). Man of Aran. New York: M.I.T. Press.

O'Laoghaire, Liam. 1945. Invitation to the Film. Tralee: The Kerryman.

Ó Catháin, Brian. 2004. "Oidhche Sheanchais le Robert J. Flaherty: An Chéad Scannán Gaeilge dá nDearnadh". Bliainiris 2004. Ed. Ruairí Ó hUiginn and Liam Mac Cóil. Ráth Cairn, Co. na Mí: Carbad. 151-235.

Ó Conluain, Proinsias. 1953. Sceál na Scannán. Baile Átha Cliath: Oifig an tSoláthair.

Ó Dónaill, Niall. 1977. Foclóir Gaeilge-Béarla. Dublin: Stationery Office. http://www.teanglann.ie/ . Accessed14/7/2015.

Ó Duilearga, Séamus, ed. 1934. "Miscellanea”. Béaloideas 4.4. 455.

O'Leary, Philip. 2004. Gaelic Prose in the Irish Free State: 1922-1939. University Park, PA: The Pennsylvania State University Press.

Ó Súilleabháin, Seán.1970. A Handbook of Irish Folklore. Detroit: Singing Tree Press. 411.

"Our London Letter: Irish Story-telling Filmed".1934. Irish Independent 1 February. 8.

Robinson, Tim. 1986: Stones of Aran: Pilgrimage. London: Viking.

Rockett, Kevin. 1996. The Irish Filmography. Dún Laoghaire: Red Mountain Media.

2003. "Irish-language films". The Encyclopedia of Ireland. New Haven, CT: Yale University Press. 544.

Roinn an Oidea ais. 1934. Oi e ean ais: Sean-Scéal a innsi eann Seáinín Tom eáin as Árainn. Dublin: Roinn an Oidea ais.

Roinn Oideachais, An.1986. Foclóir Póca. Dublin: An Gúm. 
Seanad Éireann Debates. 1935. "Irish Language and Public Services-Motion”19.22.10 April. http://oireachtasdebates.oireachtas.ie/. Accessed 22/4/2014.

Stoney, George. 1978. How the Myth was Made (58 minute film).

“Subsidised by State - Irish 'Talkie': New Dictionary: Plans for Research”. 1934. Irish Press 19 December. 11.

Sumner, Natasha, Barbara Hillers, and Catherine McKenna. 2015. "A Night of Storytelling and Years in the 'ZCloset': The Re-discovery and Restoration of Oidhche Sheanchais, Robert Flaherty's 'Lost' Irish Folklore Film". Folklore, 126:1. 1-19.

Synge, J. M. 1920 (1906). The Aran Islands. Dublin: Mausel \& Company, Ltd.

"Three Men Feared Lost”.1939. Irish Independent 2 August. 9.

Ungar, Steven. 2011. 'Review: 'The Adventure of the Real: Jean Rouch and the Craft of Ethnographic Cinema' by Paul Henley". Film Quarterly 65.1 (Fall). 73-4.

Williams, Deane. 2002. "Robert Flaherty". Senses of Cinema 23. http://sensesofcinema.com/2002/greatdirectors/flaherty/ [retrieved: 30/09/2015]

Winston, Brian. 1999. "Documentary: How the Myth Was Deconstructed”. Wide Angle 21.2. 71-86.

\section{Archives}

Flaherty Papers, Rare Book and Manuscript Library, Columbia University in the City of New York. Scrapbooks, Dublin Evening Mail, 19 March 1935.

Modern Books and Manuscripts Collection, Houghton Library, Harvard University.

Oidhche Sheanchais [motion picture], directed by Robert Flaherty, MS Ir 36. Accessed between 29 January 2015 and 5 February 2015.

Oidhche seanchais: sean-scéal a innsigheann Seáinin Tom Sheáin [pamphlet]. 1934. Saorstát Éireann: Roinn an Oideachais.

Moses and Frances Asch Collection, Smithsonian Institution Archives.

Sidney Robertson Cowell Recordings, Track 12 (Maggie Dirrane: Baile an Róba), FW-ASCH-5RR-5247, 1955. Accessed 28 August 2014.

The National Folklore Collection, UCD.

NFC 287: 62-80; Seáinín Tom Ó Dioráin (62), An Sruthán, Árainn, County Galway. Collector: Séamas Ó Duillearga, January 1934.

NFC: Oidhche Sheanchais folder; business correspondence from John Goldman letter to Séamus Ó Duilearga 20 April 1934 (1 page).

Received $13^{\text {th }}$ August 2015 Last version $9^{\text {th }}$ December 2015

Tomás Ó h-Íde (Ihde) received a Ph.D. in Applied Linguistics from the University of Dublin (Trinity College) in 1998. He lectures in the Irish Language section of the Department of Languages and Literatures at Lehman College of the City University of New York. He has served as Director of the CUNY Institute for Irish-American Studies and President of the North American Association for Celtic Language Teachers. He was primary author of the books The Irish Language in the United States (1994) and Colloquial Irish (2008). 